\title{
The Study of Indigenous African Music and Lessons from Ordinary Language Philosophy ${ }^{1}$
}

\author{
Madimabe Geoff Mapaya \\ University of Venda \\ Email: geoff.mapaya@univen.ac.za
}

\section{Doi:10.5901/mjss.2014.v5n20p2007}

\section{Abstract}

This paper is based on the study that examined peculiarities of the indigenous African music. Specifically, the study aimed to highlight the inadequacies of canonised (ethno)musicological methodologies. Participative observations, including dipoledišano (interviews), were used to gather data about indigenous African music over a period of five years. Particular attention was given to explications of the baletši (indigenous practitioners). Considering the baletši's perspective, the study found that the study of African music seems misaligned with indigenous African music practices. Consequently, attendant fabrications usually packaged as theories or philosophies about, and on the phenomenon by some scholars are self-serving, and at worst, moot. These theories seem to be scantily relevant insofar as the advancement of scholarship in African music is concerned. Furthermore, the results show the existence of African ways of conceiving, comprehending and communicating knowledge about indigenous African music. For this and other reasons, it becomes prudent to propose what could be known as Ordinary African Musicology, which would be capable of harnessing the best of both worlds; traditional scholarship and African folkloric epistemologies.

Keywords: African musicology; indigenous African music; ethnomusicology; post-colonial studies; cultural music; African music.

\section{Introduction}

European explorers and missionaries encountered African music as early as the nineteenth century. But it was only in 1947 in South Africa and later through the inauguration of the Society for Ethnomusicology in the United States in 1955 that the music began to attract scholarly attention (Agawu, 1992). Before this development, the music was documented and studied primarily for other than musicological reasons. Its study, for instance, served as a way through which insight into the culture or religiosity of Africa was to be construed (Mapaya, 2013). It was, often by circumstance, the subject of sociological, ethnological and anthropological interests. Yet, through all these encounters, indigenous music emerged with its fundamentals intact. But what is indigenous African music?

The concept, indigenous African music, interchangeable with traditional African music, refers to an aggregation of regionally, customary, culturally and ethnically constituted musical practice commonly christened in the Sesotho languages as mmino wa setšo. At the centre of this phenomenon lies the stoicism of cultural experts who have maintained its philosophical, spiritual and intellectual foundations and integrity. This was achieved by clearly compartmentalising it into setšo (-of origin or cultural) as opposed to sebjalebjale-a kind of modernity (Mapaya, 2010). In short, baletši ba mmino wa setšo (cultural music practitioners), here shortened as baletši, are the ultimate bearers of these kinds of indigenous knowledge genres. They have over many years of exposure acquired performative skills through partaking in various rituals and socialisation processes. Most believe their prowess is an endowment from badimo (ancestors), which manifest in talent traceable back to one's parents (Merriam, 1982). Yet role players in the study of mmino wa setšo are almost exclusively ethnomusicologists, who are essentially non-African 'music' scholars, and African scholars who up to now have been trained in one or the other western music tradition. In line with this observation, Nzewi (1997) speaks of the culture-exponent, the culture-owners and the culture-bearer ${ }^{2}$ or what is referred

\footnotetext{
${ }^{1}$ This is a reworked paper that was presented at the 2013 Africa Conference under the theme, Social Movements, Religion, and Political Expression in Africa, held at the University of Texas at Austin, USA. I wish to thank the Research and Publication Committee of the University of Venda for funding my conference attendance.

2 The culture-exponent is a reliable African voice in ethnomusicology or musicology, whose cognisant insight and original analytical creative contributions will advance authentically African scholarship in African music theory, pedagogy, and creativity, whereas the culture-owner is a modern trained African whose modern musical training of any level, bias content and philosophical orientation has disabled his/her initiative to formulate independent opinion; and who is further, not mentally emancipated to respect or accept his/her
} 
to in this article as baletši. According to him, only the culture-exponent provides a reliable African voice even though his or her contributions are inchoate or marginalised. What is noteworthy though is that in his book titled African Music: Theoretical Content and Creative Continuum: The Culture Exponent's Definitions, Nzewi only allocates a paragraph to the culture-bearer, while being generous in illuminating the culture-exponent's contributions, concepts and definitions. Clearly, scholarly discourse about mmino wa setšo and similar types of practices seem to machinate a plot of obliterating the 'voice' of baletši. In its place opinions of scholars of different hues packaged largely as theories, often heralded as the only viable or the ultimate expressions of these kinds of knowledge genres are preferred. This is generally the problem centrally associated with the African Studies or studies about Africa originating from Europe and lately the United States of America.

Although not explicitly declared, however, the study of African music, like most of the human and social sciences, is gradually ridding itself of the problems associated with the tendencies of the erstwhile tradition of scholarship. Postcolonial impulses from all angles seem to be conspiring to dislodge the Eurocentric hegemony, which has so far become the only prism through which scholarship has been viewed. Inspired by a melange of post-colonial impulses, especially theories closely associated with the invocation of the African worldview such as the Afrocentric paradigm (Asante, 1987;1988; 1995), this paper proffers a critique of the so-called established fields; namely ethnomusicology and musicology - two fields of study variously involved or concerned with the study of the indigenous music of Africa. Imbedded in the critique is the question of agency-a concept at the heart of the motivation of role players within the African music research enterprise. In conclusion the paper advocates for a musicology amenable to the philosophies of baletši-a paradigm akin to ordinary language philosophy (Snowdon, 2006; Fasiku, 2008; Mungwini, 2011).

\section{Ethnomusicology and the Study of African Music}

Mmino wa setšo or indigenous African music has been in existence from time immemorial. Since its inception, ethnomusicology has claimed centre stage in the study of African music, even though mainstream musicology, or the 'formal' study of music, predates it. Eschewed by this mainstream musicology, in the nineteenth century mmino wa setšo became the subject of the then new discipline known as vergleichende Musikwissenschaft, which translates to comparative musicology (Merriam, 1977; Nettl 1991; Waterman, 1991), which later transmogrified into ethnomusicology. But deducing from criticisms by scholars such as Agawu (2008), Connery (2009), Kidula (2006), Kingsbury (1997) or even Rhodes (1956), ethnomusicology of the Chase (1958) through to the Feld (1974) eras was in many respects less than ideal.

First, ethnomusicology has not broadened the scope of the indigenous African music repertoire; nor has it trained students towards culture-sensed performative practices. Since mmino wa setšo songs and dance are specifically communalty contrives, there is little space for further or additional compositions especially from those who are perceived to be outside the culture. Rather those inside the culture extemporise the song text and improvice dance routines as dictated to by the the topical or political environment and circumstances, but never deviating from communal compositional parameters and ethos (Sekiba, 2005; 2012).

Second, ethnomusicology exogenous character coupled with its legacy of being anthropology's 'stepchild' and "a second class citizen in the society of the social sciences and the humanities" (Rhodes 1956, p. 457) has, in post-colonial times, dented its reputation. With the ascension of the African voice within the academe and the awakening by scholars in general to post-colonial realities, ethnomusicology no longer enjoys the authoritative status when it comes to study of African music. It is, in fact, viewed with some level of scepticism. Not intended to deal solely with African music, ethnomusicology is rather designed, much like anthropology, to focus on non-European musics; African music included (Connery, 2009). Scholars such as Kingsbury (1997) see it as the "institutionalisation of an epistemological double standard; examination of social interaction which generates musical experience [which is] specific to the study of 'other's musics" (p. 284). Like anthropology, which is often linked to colonialism and imperialism, and generally helping to develop the image of the 'savage' as Steady (2004) puts it, ethnomusicology will find it hard to escape this level of post-colonial scrutiny.

Third, since its inception, it has failed to distil content for classroom purposes on the African continent and elsewhere; nor has it succeeded in improving the material conditions of baletši, let alone improving the quality of the music itself; this despite the benefit of the groundwork already laid by disciplines such as anthropology. Everything about

culture's mental integrity as a guide; The culture-bearer, on the other hand, refers to the accomplished traditional or neo-traditional music practitioner who knows and practices music without the modern training or orientation to articulate the theories and processes of his/her culturally rationalised musical experiences and product (see Nzewi, 1997:16-17). 
indigenous African music is still the same, and in some cases, worse than it was before the advent of ethnomusicology. And lastly, ethnomusicology succeeds in reproducing itself. Universities in Europe, America and elsewhere continue to churn out non-African scholars who go on to specialise in African Studies, indigenous African music included.

Worryingly though is that this scepticism is not entirely new. Wachsman $(1969,164)$ wrote, "[m]usicology by itself is bad enough; but in conjunction with the prefix "ethno" it offends many people." Perhaps this explains why Worsley (1997), in general terms, questions the intentions of academe which prefers the prefix 'ethno-' when dealing with knowledges of other cultures. Furthermore, Agawu (1992) still questions whether ethnomusicology is a subfield of musicology, ethnology, anthropology, sociology or a stand-alone discipline. To its credit though, ethnomusicology has ushered in an era of a kind scholarly interest in the African music, albeit self-serving. Although it has served indigenous African music with some measure of success, especially by placing it in the purview of academe, the need for an indigenous African music specific mode of inquiry is required if the study of this kind of music is to benefit scholarly development. Such a mode of inquiry could operate at programmatic and methodological levels within the overarching field of African musicology. Perhaps different from the current ethnomusicological modes of enquiry, where the scholar's mediation reigns supreme, the new orientation to African musicology should seek to place the baletši's ideations on par with the theories of the scholars; not to subsume them as is the case.

\section{Musicology and the Study of African Music}

The study of African music is entangled in a multifaceted fundamental problem. Firstly, barring its composite nature, that is, its conjoined nature with dance, costume and other surrogate or allied art forms (Mapaya 2013), indigenous African music is after all music; and music is music (Babbitt, 1958; Chua, 1999; Cook, 2000). As such, it should, at least, warrant musicological treatment. In other words mmino wa setšo cannot be immune to analysis and all other forms of musicological investigation, for as long as such do not compromise its composite and live or performative nature.

Granted, the idea of indigenous African musicology brings into contention what may be regarded as stereotypical adjectives such as indigenous and African. Whether this is good or bad is for this study immaterial, for as Bachlund (2012) puts it, "[m] usicology is conducted in words and not in music." Furthermore, language, with all its cultural nuances pregnant of material and philosophical wealth is the medium of musicology (Nedergaard-Larsen, 1993). Granted, to think or talk of African, European or any other music, for that matter, is both a convenience as well as a popular academic indulgence; otherwise music is to performance. From this premise, one may argue that indigenous African musicology should have some articulation with mainstream musicology. By dislocating it from such, inevitably relegates it to the trappings of ethnomusicology where the power politics of academe are unduly energised and justified.

For, by starting from ethnomusicology, a leeway is created for commentators who do not necessarily have a firm undergraduate grounding in musicology or the benefit of adequate lived-experience to claim a place in the field of the study of African music. Whereas valid arguments supporting this way of entering this field may exist, such approaches are, at times antithetically suggesting that the study of African music does not warrant a systematic and scientific approach. Mere recorders of cultural encounters including other types of anthropologists, ethnologists and sociologists can write about it and then inaugurate themselves as experts. These are some of the root courses of many a problem bedevilling the study of indigenous African music today. Only when musicologists of the ilk of Reverent A.M. Jones and Percival Kirby entered the fray did we see substantive musicological content and fact coming out of the study of the music. These icons indeed represent a corpse of noble musicologists whose work could be emulates. The only problem with these musicological advancements, however, is that their application is still outside the purview of the baletši's language, and therefore manner of musicologising. For this, and other reasons, African musicologists such as Agawu, Euba and Mugovhani justifiably dispute certain musicological theories, conceptions and perceptions.

Besides these problems, musicology, deemed the older 'science' by the early scholars such as Adler, Pratt, Sonneck, Seeger, Riemann, and Kinkeldey (Harap, 1937; Schweiger, 1940), is not immune to challenges that besiege other disciplines, especially in the post-colonial era. Characterised as "part of the nineteenth century nationalist project: where early musicologists saw themselves as musical philologists" (Cook 2005), musicology is seen as consisting branches of musical knowledge such as theory, history and to some extent acoustics. Responding to Lieberman's 1976 poser, "Should ethnomusicology be abolished?", Helm (1976) implies the affirmitive by asserting that musicology is "everything musical except performance and composition". In other words, "what we do musically when we put our instruments down, when we stop singing, when we stop composing." Furthermore, since it has little to do with performance, it is accused by scholars such as Cook (1999) of "primarily concerning itself with scores," musicology is concerned mainly with the '-ologies' of western forms of music, while neglecting or ignoring what the West relegates to folk or popular music. 
Be that as it may, the assertion that African praxis is devoid of theory or couched in what is referred to as 'ineffable knowledge' (Raffman 1993) or 'performative ethnology' (Erlmann 1996), is one that goes against the philosophy that says "music is music, is music is music". As to why most writings about the study of African music seem to shy away from musicology as a starting point, choosing rather to see ethnomusicology as the most logical province should be a matter of concern. The notion of African musicology should be allowed space to exist; and to blossom musicologically without being cluttered by the sins of musicology and ethnomusicology.

\section{African Musicology and the Study of African Music}

From within the ranks of ethnomusicology the post-colonial urge necessitated the birth of an orientation christened African musicology. Since its infant stages around the 1960s, African musicology was never explicitly defined but merely implied or embedded within ethnomusicology. It was only in the last three decades that some African scholars insinuated, and in some instances argued that African musicology is a markedly different mode of academic inquiry or discipline from ethnomusicology. African scholars, particularly those grounded in musicology through their undergraduate training increasingly began fancying themselves as (African) musicologists, as opposed to ethnomusicologists (Kidula 2006). Nevertheless, it is still expected of a 'respectful' scholar of African music to be familiar with the works of leading scholars who contributed to the establishment of a broad body of literature on African music. This list of pioneering authors includes Simha Arom, John Blacking, John Chernoff, Dave Dargie, Reverend A.M. Jones, Gerhard Kubik, Allan P. Merriam, Bruno Nettl, David Rycroft, Ruth Stone, Percival Kirby and Hugh Tracey-all self-styled as ethnomusicologists revealingly of European descent. Some of their work is accessible from the African Music Journal, housed at the International Library of African Music (ILAM) in Grahamstown, South Africa.

That aside, though, the idea of 'African musicology' owes its root to the work of one Kwabena Nketia. Most scholars today agree that the most important work by an African scholar is Nketia's 1964 publication titled The Music of Africa. In addition, Nketia authored many a conference papers and published articles that are more musicological in their thrust. His body of work is seen by many as the fulcrum, and perhaps the epitome of what is called African musicology today. For instance, a tribute in the form of a collection of essays titled, African Musicology: Current Trends (1992) edited by Jacquelyn Djedje was published. Coming in two volumes, it features, amongst others, contributions by esteemed scholars such as Mensah, Mosunmola, and Omibityi-Obidike. This collection of essays therefore marks a decisive point in history towards the establishment of a discipline known as African musicology. But, it would take many other scholarly contributions to realise such a discipline. Francis Bebey's book African Music: A People's Art published in 1975 comes a close second to Nketia's in the pioneering stakes (Agawu, 2003). These works and a few others could be said to have opened the floodgates in respect of African musicology for scholars such as Akin Euba, Joshua Uzoigwe, Kofi Agawu, Lazarus Ekwueme, Meki Nzewi, Mwesa Mapoma, and Samuel Akpabot. This corps of musicologists has in turn continued to play the midwifery role in initiating many younger African musicologists. Regardless of these developments, African musicology is yet to be thoroughly articulated as a distinct field of study alongside musicology and perhaps ethnomusicology. Suffice to say, in the last quarter of a century, African musicology has taken root, especially in the western part of the continent. The establishment of the Musicological Association of Nigeria (MAN) in 1993 at llorin, which later became the Association of Nigerian Musicologists (ANIM), was to be followed by the formation of the Bureau for the Development of African Musicology in 2006, in Malaysia. These developments gave birth to the Journal of the Association of Nigerian Musicologists (JANIM) and the African Musicology Online Journal respectively.

On the African continent, where funding for research has been dwindling, splitting musicology from ethnomusicology has made little sense. Furthermore, it would take a country such as South Africa with its bad history of the separate development project notoriously known as apartheid to collapse these dichotomous entities into one. After all musicology and ethnomusicology are all disciplines engaged in research about music. It was therefore not amiss that at a historic joint meeting of the former Musicological Society of Southern Africa and the Symposium on Ethnomusicology held at the University of Cape Town South Africa in 2005, the idea of merging the two organisations into one was mooted. This ideal was eventually achieved at the Potchefstroom conference the following year, where a new society, the South African Society for Research in Music (SASRIM), came into existence. This development decisively bridged the divide between musicology and ethnomusicology by expressly aiming to promote and foster research on music in South Africa through a single conference and a single journal publication.

Conclusively, the coming into being of the idea of African musicology is the result of the ideological as well as the political reawakening primarily by African scholars with a musicological background to the post-colonial developments within the field. In other words, the idea of African musicology can be seen in political terms as the emancipation of African scholarship. African scholars, not only yielding to circumstances, are now, together with other progressive non- 
African scholars, becoming agents of change. But this change would not have been possible without an appreciation of the ravages of colonialism in all its guises.

\section{Parameters of African Musicology}

To understand the parameters of African musicology, one needs to have knowledge of the conceptual framework of African music genres, understanding and appreciation of performance intentions and incentives and many other real and metaphysical dimensions including the role of language in performative contexts. For instance, most African music genres are in fact song-dance compounds. Song is often accompanied by dance and vice-versa. A song may be vocalised or played on an instrument, while dance is a bodily execution. The rhythm of song, which is usually enhanced or complemented by the drum, is responsible for instigating bodily responses or gestures the most elaborate and stylised of which being dance. Secondly, the dance, most often through its different stages of energy levels leads to some spiritual elevation. At the highest level of signing, instrument playing and dancing is a climax which manifest in numerous forms of incentives. Performer, at this level, often experience a sense of escaping all manner of physical and spiritual limitations. Some experience healing while others transcend into the spiritual realm where they readily become medium of badimo/badzimu (ancestors).

A significant number of song performances are accompanied by drumming (sometimes on imaginary drums). Good rhythmic execution in both singing and on drumming translates into 'perfect' dancing, and good dancing energises singing even more; And so goes the spiral regeneration layer after layer of a performance until the highest point of spiritual elevation is reached. Another role of the drum is that of marrying the song with the choreography or dance routines. So ingrained is this philosophy of song and dance to the extent that astute practitioners of indigenous music are able to 'hear' the song through the sight of dance routines only, and conversely 'see' or imagine accompanying dance routine by just hearing the song. It is because of this 'compoundedness' of African music that scholars such as Kirby (1933), Nettleton (2006) or Mutele and Musehane (2012) can be excused for using nomenclature such tshikona dance, domba dance and so on and so forth when referring to the song and dance compound. Thirdly, acknowledging that indigenous African music primarily exists in performance, means half the battle is won because talk about it constitutes musicology, especially when such talk encapsulate elements such as descriptions, definitions, analysis and characterisations of the practice with the aim of accurate representation. Most importantly, such talk should also be sensible to baletši. Relying or invoking African philosophy in the process constitutes African musicology.

Not belabouring the point any further, indigenous thought patterns may understandably not necessarily correspond with those of the West. Whereas a significant number of western music performances aim for linearity in its logic, for instance, African music often spirals upwards (Mapaya, 2013). Most western music is based on the principle of the home key; that is, the act of composing and performing aims to begin and come back to end on the home key. In other words, it starts on the home key and meanders back to that very key or its derivatives. Against this background, one understands the much-publicised notion of African music being cyclic. How this is achieved forms a greater part of the theory and analysis, form and compositional techniques. Transported into ethnomusicology, this notion (of cyclicity) is raison d'être. Recently, Nzewi (1997) has refashioned it as the Ensemble Thematic Cycle (ETC) philosophy.

\section{Rationalising Ordinary ${ }^{3}$ Language Musicology}

Since indigenous African music is essentially a communal construct, its dependence on African language should, in line with Hallen's ordinary language philosophy theory (cited in Fasiku 2008, 105), be ordinary, common and enjoying collective usage in what could be equivalent to, or regarded as musicological description and analysis-in short musicology. In this regard, the idea of ordinary language musicology derives directly from the idea of ordinary language philosophy. Ordinary language musicology should therefore be viewed as a paradigm of music scholarship that dutifully allows space for indigenous African abstractions, vocalisations and ideations to take centre stage in academic discourse. Accordingly, investing in the use of natural or ordinary African languages when dealing with indigenous African music is sensible since the phenomenon is natural within particular contexts. Gerring and Barresi $(2003,203)$ rightfully reason, "[n]atural language makes sense to its users." Puzzled by the penchant of scholars to coin and also to impose

\footnotetext{
3 The enlisting of the concept 'ordinary' as used in this paper, and indeed as it obtains within the ordinary language philosophy paradigm, is devoid of denigration. It should rather be seen as an honest anti-elitist philosophical stance designed to bring the so-called nonEuropeans into the mainstream of scholarly discourse. Nonetheless, ordinary is both natural and simple but profound in that it is understood by a large section of the community.
} 
terminology, they question why natural or ordinary language, and by implication indigenous terminology, should not make sense to academics.

Ethnomusicology, against the foregoing arguments, facilitates the dwarfing of African epistemes by imposing, and in some instances, clamouring on exogenous languages biased explications, while ignoring African rationality; this in favour of scholarly inventions that reside outside the purview of baletši and the practice. Is it not illuminating that only an insignificant number of terms, predominantly names of instruments, have found their way into the ethnomusicological discourse? Mbira ${ }^{4}$ for instance, was once referred to as kaffir piano (Jones, 1959). This nomenclature was later toned down, as it were, to mean hand piano; then thumb piano (Akpabot, 1976).

Names are but one tiny component of language. As such, limiting access to the study of indigenous African culture to just names, for instance, only diminishes the grasp of the germane philosophical underpinnings. For the same reason, studying African musical thought using a non-African language for purposes of access or without investing in the deep functional understanding of that language leads to flippant coinages such as the kaffir piano. Perhaps this fact constitutes the greatest irony since ethnomusicology claims to be more contextually relevant than musicology. How contextually relevant is the language of discourse, or the books that swell libraries the world over?

Undoubtedly, Africa has its own indigenous systems that deal with the metaphysical and the epistemological aspects of their existence. Despite the threat of epistemecide, these systems have persisted while coded in orality. The systems are encoded within the African languages; both specialised and ordinary. Besides burying these epistemologies within specialised language forms, other strategies exist which fulfil the function of maintaining intellectual integrity of indigenous knowledge systems. Bahananw ${ }^{6}$ for instance, have compartmentalised worldviews by drawing a dichotomous divide between setšo (tradition ways), sekgowa (white man's ways) or sebjalebjale (modernity).

Philosophers seem to have had a head start in acknowledging the validity of ordinary language, hence the establishment of the ordinary language philosophy paradigm. The existence of African philosophy would be a fallacy if there were to be no regard for African languages. In this regard, ordinary African language could be viewed as a key precondition for this philosophy to existence. Fasiku $(2008,100)$ insists, "If African philosophy exists, we should show it, do it and write about it rather than talking about it, or engaging in endless talk about it." I guess, if indigenous African musicology exists, we should, most importantly, show it. We should meet it at its organic site of existence, do it, and write about it rather than leave it obscured from academe. After all, the ability to recall past instances of performances (historical), rationalisations and manufacturing of instrument (technology), the arrangement of the order and tuning of reed pipes (theory), execution of thematic build ups within musical performance (praxis) and so on, represent the site at which indigenous African musicology exists. If an awareness and access to such systemic manifestations of indigenous music systems exists, then baletši and those genuinely interested in indigenous African music should together 'musicologise' about it.

One site where baletši express their meaning in discursive terms is upon the occurrence of an error, where musical ideas are dutifully given expression (Agawu 2001). In Northern Sotho, specialised usage as in proverbs, praise poems and idiomatic expressions are common amongst baletši. In fact, such language usage forms one of the major modes of musicological commentary. Mamoleka (2012) informs that when she is not happy with the accompaniment she is getting from group members, o hlaba seka a dutšo a opela (she resorts to idiomatic expression during her extemporisation to raise her concern):

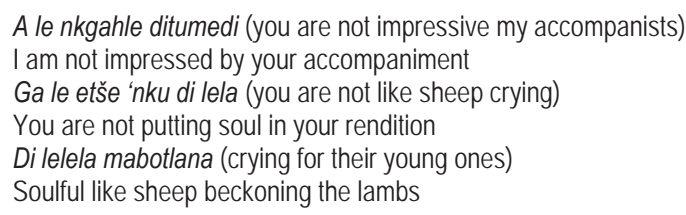

In the preceding example, the leader of song records, in flight as it were, her discontentment with the manner in which her 'backing vocalists' or 'accompanists' responds to her lead singing. In the same breath, she depicts the kind of vigour she is expecting from them by resorting to the rich element of speech called depiction. The philosophy of African proverbs is yet another aspect of language that enriches both musical expression and discourse (Nzewi, 2007:29-30).

\footnotetext{
${ }^{4}$ Mbira is an ancient instrument that is made out of wood and pieces of metal, played by way of plucking the flattened metals, fastened to the wood by means of a string and adjusted in a manner that is representative of the tonal system of particular African people.

${ }^{5}$ Kaffir is an insulting and contemptuous term used during apartheid by whites to refer to an African.

${ }^{6}$ Bahananwa is one of the Northern-Sotho speaking ethnic groups of South Africa.
} 
D'Angelo $(1977,365)$ defines proverbs as; "short, concise sayings in common use which express some obvious and familiar truth or experience in striking form." There exists a fine line between African proverbs and theory as encountered in academic discourse. Proverbs can also inform a theoretical framework (Avoseh, 2013). Pursuing this could perhaps be a matter for further study.

For now, let us briefly inspect the philosophical benefits of the following instances by way of investigating Northern Sotho proverbs, followed immediately by literal translation, and interpretation.

Sa koša ke lerole (literal translation: what belongs to a song is dust). It is only considered a song if it is performative (implicating singing and dancing). In other words, what constitutes a song is performance. a song does not exist outside its performance.

Koša e botse ka diala (literal translation: musical performance is splendid if decorated in costume and props). African dances find their visual appeal partly through the choice of costumes, makeup and body painting together with other complementary artefacts. (Masasabi, 2007:8). Therefore, musical performance thrives in the usage of props.

Lešaedi ga le hlokege košeng (the spoiler is usually desirable in musical performance). There will always be an odd character (spoiler/the less talented) in any given performance. If the presence of lešaedi is not adversely detrimental to the character and integrity of indigenous African performance, then the presence of such should be enjoyed as part of the music making process.

In the examples given above, we note how the philosophy of musical performance incorporates costume and props, enhancing the different aspects of performance such as dancing and singing; and the accommodation of elements that may be considered spoilers. A study that delves deeper into these dimensions could reveal a great deal of knowledge and wisdom that so far lie outside the purview of current forms of musical inquiry, especially ethnomusicology.

\section{Conclusion}

This paper discussed issues relating to language from musicological, ethnomusicological and philosophical perspectives. Grounding the arguments was an assertion that African musicology can benefit from the ordinary language philosophical foundations. Using the indigenous African music example, I have illustrated the fact that for African epistemologies to be properly recouped, a revision of current modes of knowledge formulation within the so-called established fields of study is not enough. In contrast to many African scholars, I, instead, move for the reconfiguration or, at best, the reconstruction of these modes of knowledge production systems to the benefit of both cultural communities and academe. Specifically, I am advocating a type of musicology that takes African languages as its main vehicle of engagement between scholars and indigenous African practitioners. This language factor is bound to develop into an acceptable discursive mode within academe; especially when African epistemologies are under study.

\section{References}

Agawu, K. (1992). Representing Africa. Critical Inquiry, 18(2), 245-266.

Akpabot, S. E. (1976). Fugitive Notes on Notation and Terminology in African Music. The Black Perspective in Music, 4(1), 39-45.

Asante, M. (1987). The Afrocentric Idea. Philadelphia: Temple University Press.

Asante, M. K. (1988). Afrocentricity. Trenton, NJ: African World Press.

Asante, M. K. (1995). More thoughts on the africanists' agenda. A journal of opinion, 23(1), 11-12.

Association of Nigerian Musicologists (n.d.). Association of Nigerian Musicologists.[Online] Available: http://www.nigerian musicologists.org/(June 6, 2013)

Avoseh, M. B. (2013). Proverbs as theoretical frameworks for lifelong learning in indigenous African education. Adult Education Quarterly, 63(3), 236-250.

Babbitt, M. (1958). Who cares if you listen? High Fidelity, 8(2), 38-40.

Bachlund, G. (2012 ). On Stereotypical Adjectives to Describe Music . [Online] Available: http://www.bachlund.org/On_stereotypical_ adjectives.htm (September 28, 2013)

Chase, G. (1958). A dialectical approach to music history. Ethnomusicology, 2, 1-9.

Chua, D. K. (1999). Absolute music and the construction of meaning (Vol. 4). Cambridge: Cambridge University Press.

Cook, N. (2000). Music: A very short introduction. Oxford: Oxford University Press.

D'Angelo, F. J. (1977). Some uses of proverbs. College Composition and Communication, 28(4), 365-369.

Fasiku, G. (2008). African philosophy and the method of ordinary language philosophy. The Journal of Pan African Studies, 2(3), 100116.

Feld, S. (1974). Linguistic models in ethnomusicology. Ethnomusicology, 18(2), 197-217.

Jones, A. M. (1959). Studies in African Music (Vol. I). London: Oxford University Press.

Kidula, J. (2006, Spring). Ethnomusicology, the music canon, and African music: Positions, tensions and resolutions in the African 
academy. Africa Today, 52(3), 99-113.

Kirby, P. R. (1933). The Reed-Flute Ensembles of South Africa: A Study in South African Native Music . The Journal of the Royal Anthropological Institute of Great Britain and Ireland, 63, 313-388.

Lieberman, F. (1976). Should ethnomusicology be abolished? Position papers for the ethnomusicology interest group at the 19th annual meeting of the College Music Society, Washington D.C., November 1976. (A. R. Paper, Producer) Retrieved March 14, 2012, from Aspects of the Profession.

Mapaya, M. G. (2010). Music of Bahananwa: History, soundscape and aspects of contemporary transmission of Sehananwa culture through music. Saarbrücken: VDM Publishing House Ltd.

Mapaya, M. G. (2013). Investigating mmino wa setšo (indigenous african music) as practiced by Bahananwa in Limpopo province, South Africa: Towards ordinary african musicology. PhD Thesis, University of Venda, Thohoyandou.

Masasabi, A. (2007). The face of African music in the Kenya music festival foundation. African Musicology Online, 1(1), 1-13.

Merriam, A. (1982). African music in perspective. New York: Garland Publishing INC.

Merriam, A. P. (1977). Definitions of the "comparative musicology" and "ethnomusicology": An historical-theoretical perspective. Ethnomusicology, 21(2), 189-204.

Mungwini, P. (2011). Orality and ordinary language philosophy: revisiting the intellectual heritage of Africa's indigenous cultures. Southern African Journal for Folklore Studies, 21(2), 1-11.

Mutele, T., \& Musehane, N. (2012). The prospects and challenges of women in leadership positions. A case study of Thulamela municipality. International Journal of Humanities and Social Science, 2(23), 226-229.

Nedergaard-Larsen, B. (1993). Culture-bound problems in subtitling. Perspectives, 1(2), 207-240.

Nettl, B. (1991). Comparative musicology and anthropology of music. Chicago: University of Chicage Press.

Nettleton, A. (2006). Samson Mudzunga, Dzingoma, and New Mythologies . African Arts , 63(4), 68-77, 95-96.

Nzewi, M. (1997). African music: Theoretical content and creative continuum: The culture exponent's definitions. Oldershausen: Institut fiir Didaktik Popularer Musik.

Nzewi, M. (2007). A contemporary study of musical arts informed by African indigenous knowledge system: Illuminations, reflections and explorations (Vol. 4). Pretoria: Ciimda.

Sekiba, W. (2005). Face-to-face interview. (M. Mashao, \& K. Setati, Interviewers) Burgersfort, Limpopo Province, South Africa.

Sekiba, W. (2012). Discussions on dipela. (M. MG, Interviewer) gaKobe, Limpopo Province, South Africa.

Snowdon, P. (2006). Ordinary language philosophy. Encyclopedia of Language \& Linguistics, 84-87.

Waterman, C. (1991). The uneven development of Africanist ethnomusicology: Three issues and a critique. In B. Nettl, \& P. V. Bohlman (Eds.), Comparative musicology and anthropology of music: Essays on the history of ethnomusicology (pp. 169-86). Chicago: University of Chicago Press.

Worsley, P. (1997). Knowledges: What different peoples make of the world. London: Profile Books. 